\title{
Salafi Tafsirs: Textualist and Authoritarian?
}

\author{
Izza Rohman $^{1}$
}

\begin{abstract}
Absract
This essay looks at some Salafi tafsirs to examine the extent to which their interpretation ignores or rejects both the sociohistorical context of revelation and that of interpretation, and the extent to which their interpretation denies any possibility to understand the text differently. Taking the hijāb verses as a case study, the author shows similarities and differences between the three tafsirs under scrutiny in terms of their "textualism" and "authoritarianism".
\end{abstract}

Keywords: Salafi tafsir, textualism, authoritarianism, women's issues.

\section{Introduction}

In his works, Khaled Abou El Fadl has many times characterized contemporary Wahhabi-Salafis' reading of Islamic (legal) texts as "authoritarian" and "ahistorical" (as well as other attributes he also mentions). ${ }^{2}$ His criticism, however, is based on a thorough analysis of the fatwas - many of which are related to the issue of women in Islam - issued by organizations and scholars representing the group — whose discourse to Abou El Fadl has been to a large extent prevalent in many contemporary Muslim societies, even among Muslims in America. The fatwas he examines themselves are far more often based on a certain understanding of hadith, rather than on a particular

${ }^{1}$ Dosen Universitas M uhammadiyah Prof. Dr. Hamka (UHAMKA) Jakarta. Email: lagilagi_izza@yahoo.com

${ }^{2}$ See his books, Speaking in God's Name: Islamic Law, A uthority and Women (Oxford: Oneworld, 2001) and And God Knows the Soldier: The Authoritative and A uthoritarian in Islamic Discourse (M aryland: University Press of A merica, 2001). He defines "authoritarianism" as "the act of 'locking' or captivating the Will of Divine or the will of the text into a specific determination, and then presenting this determination as inevitable, final and conclusive," (Speaking in God's Name, 93) or "a hermeneutical methodology that usurps and subjugates the mechanisms of producing meaning from a text to highly subjective and selective reading." (Speaking in God's Name, 5). B asically it is an act of closing an open text (the Qur'an), of presenting the text as having a single meaning. 
interpretation of the Qur'an. Can thus Abou El Fadl's thesis be applied to Salafis' Qur'anic exegeses? Is an authoritarian and ahistorical kind of interpretation also reflected in their tafsirs?

With regard to Salafis' Qur'anic interpretation in particular, some scholars have come to similar conclusions but in varied terms. Abdullah Saeed has in a few words categorized them as clearly part of "textualism" or "literalism". ${ }^{3}$ Following Saeed, but with a broader case of interpretation of Islamic texts, Adis Dudireja concluded that their manhaj (method) is "literalist" or at best "semi-contextualist". 4 Similarly, Quintan Wiktorowicz, a political analyst specializing in Wahhabism, characterizes Salafis' approach to the Qur'an as heavily reflecting an "opposition to rationalism"--demonstrated for instance in their interpretation of àyāt al-șifàt (verses on God's attributes) and tawhïd-related verses. ${ }^{5}$ However, while they commonly identify the Salafis as Wahhabis, none of these scholars have analyzed their approach to the Qur'an through a close look at (modern) Salafi tafsirs - which are absent in their bibliographies. To what extent then can Salafi tafsirs be categorized "textualist" or "literalist" and "opposing rationalism"?

This paper seeks to look at Salafis' (i.e. Wahhabis') ${ }^{6}$ reading of Islamic

${ }^{3}$ See Abdullah Saeed Interpreting the Qur'an: Towards a Contemporary Approach (London \& New York: Routledge, 2006), 3. He identifies three broad approaches in relation to Qur'anic interpretation (particularly its ethico-legal content) in the modern world: textualist, semi-textualist and contextualist. In this regard he defines "textualism" as "interpretation that relies on text and tradition and at the same time approaches the question of interpretation strictly from a linguistic perspective," and "that ignores or rejects the socio-historical context of the Qur'an in interpretation." (Interpreting the Qur'an, 50).

${ }^{4}$ See Adis Dudireja, Constructing a Religiously Ideal "Believer" and "Woman" in Islam: Neo-traditional Salafi and Progressive Muslims' Methods of Interpretation (New York: Palgrave Macmillan, 2011), 191-192.

${ }^{5}$ Quintan Wiktorowicz, “Anatomy of the Salafi Movement”, Studies in Conflict \& Terrorism 29 (2006), 207-239.

${ }^{6}$ While the term "Salafi" is not only used in variant meanings by scholars but also contested among those who call themselves Salafis, here the term would be used only to mean the Wahhabis (a term commonly used by non-Salafis or non-Wahhabis but they themselves rarely do so and mostly dislike to do so), particularly the "purists" (who does not form or involve in any local or transnational political movement). The word "salafi" is derived from the word "salaf" which means "predecessor". The term "al-salaf" is mostly used to denote the first Muslim generation (until the period of tābi 'ün or tābi" altäbi 'in), and is often affixed by the word șälih; al-salaf al-sălih, which literally means the "righteous predecessors". The term "Salafi" or "Salafiya" therefore means those who follow the path of al-salaf al-sălih as model examples. The term "Salafi" is often used by contemporary scholars to only mean the Wahhabis [see for instance Wiktorowicz, "Anatomy of the Salafi Movement"; Saeed, Interpreting the Qur'an; and Dudireja, Constructing a Religiously Ideal "Believer" and "Woman" in Islam], but is also equally 
texts through their Qur'anic exegeses written by three scholars from rather different generations - two of whom surely lived decades earlier than the Salafis to whom Abou El Fadl addresses his critiques. The three Salafi tafsirs involved here are: 1) Taysìr al-Karīm al-Raḥmān by 'Abd al-Raḥmān ibn Nāsirir al-Sa'di (1889-1956), ${ }^{7}$ 2) Aḍ̂ā' al-Bayān by Muhammad al-Amīn al-Shinqiți (1907-1973), ${ }^{8}$ and 3) Aysar al-Tafāsìr by Abū Bakr Jābir al-Jazā'irì (1921-). ${ }^{9}$ These three tafsirs are arguably the most popular tafsirs written by (modern)

often used to include the Wahhabis and other variants of Salafism [see for instance Abou El Fadl, And God Knows the Soldier and Speaking in God's Name], and is sometimes used to refer to non-Wahhabi Salafism, either the modernists [see for instance Abou El Fadl, The Great Theft: Wrestling Islam from the Extremists (San Francisco: HarperCollins, 2007) and Massimo Campanini, The Qur'an: The Basics, translated by Oliver Leaman (London \& New York: Routledge, 2007)] or to a much lesser extent the Ikhwanis or similar Islamists. It is important to note that one should not be confused by the term "Salafi" (or "Salafism") in its contemporary usage and the term "Salafiya" (sometimes simply "Salafi" or "Salafism") which is sometimes still used to refer to the earlier movement of the Muslim modernists like Jamal al-Din al-Afghani, Muhammad 'Abduh and Muhammad Rashid Rida. For a brief history (and anatomy) of Wahhabism, see for instance Abou El Fadl, The Great Theft, 45-94; and Wiktorowicz, "Anatomy of the Salafi Movement".

${ }^{7} \mathrm{Al}-\mathrm{Sa}$ 'di was the only Salafi exegete of Saudi origin among the three scholars discussed here. He was born and buried in 'Unayzah in the Qasim Province of Saudi Arabia. He was among the influential teachers of Muhammad ibn Șālih al-'Uthaymin (1925-2001), one of the most influential Salafi scholars who reportedly delivered lectures in the Masjid al-Haram, Mecca, for over thirty five years. Taysï al-Karim al-Rahmān is said to be the most famous among not less than a dozen of his works. For his brief biography, see his tafsir, Taysīr al-Karīm al-Raḥmān fí Tafsìr Kalām al-Mannān (Cairo: Dār al-Hadith, 2005), 11-13.

${ }^{\dot{8}}$ Al-Shinqiti (not to be confused by another al-Shinqiți who was the teacher of alSa'di or other equally prominent scholars named al-Shinqiți) was a Mauritanian scholar but later resided in Saudi after performing hajj in $1367 \mathrm{AH}$. He reportedly completed teaching tafsir in Masjid al-Nabawi twice. Initially a follower of Maliki madhhab, he was the teacher of some of the most influential Salafi figures like the former mufti of Saudi, 'Abd al-'Azìz Bin Bāz (1909-1999), and a radical figure, Ḥammūd al-'Uqlā al-Shu'aybì (1925-2002) — who was also said to be one of Abū Bakr al-Jazā'irì's teacher. See for instance Wiktorowicz, "Anatomy of the Salafi Movement", 236. In Aḍ̂ā' al-Bayān, his masterpiece, al-Shinqiți himself does not interpret the whole of the Qur'an, but he finishes at al-Mujādalah [58]: 22. The rest included in the last two volumes was done by his disciple, 'Atiyah Muhammad Salim, with Bin Bāz's encouragement. For al-Shinqītị's short biography, see his tafsir, Aḍ̂ā' al-Bayān fí Iḍạh al-Qur'ān bi al-Qur'ān (Beirut: Dār Ihyā' al-Turāth al-'Arabi, n.d.), vol. 1, 9-26.

${ }^{9}$ Al-Jazā'irī was an Algerian scholar who later resided in Saudi. A prolific scholar, al-Jaza'iri was initially well-known for his Minhäj al-Muslim, which has been translated into many languages - Urdu, French and Indonesian among others. Aysar al-Tafásìr is among his latest works and the most voluminous. 
Salafi scholars. ${ }^{10}$ Their popularity among Salafis themselves is perhaps only exceeded by such tradition-based tafsirs as Tafsir al-Qur'ān al-'Azïm by Ibn Kathir (which follows the principles and methods of tafsir outlined by his teacher, Ibn Taymiyah, a figure labeled as a "salafi par excellence") ${ }^{11}$ and Jämi" al-Bayān by Ibn Jarīr al-Ṭabari (a tafsir Ibn Taymīyah recommends most). ${ }^{12}$

In addition to revealing some of the characteristics of Salafis' approach to the Qur'an embodied in these three tafsirs, I will-for the purpose of this study-take the case of the interpretation of Qur'anic ethico-legal verses related to women's issues, particularly two interrelated issues of the rule of gazing at "unrelated" women (al-nazar ila al-ajnabijyah) and the segregation ( 'adam al-ikhtilat) between male adults and female adults. The choice to limit this to women's issues is partly because the so-called Wahhabis has often been regarded as imposing harsh restrictions on women, and also because Abou El Fadl and Dudireja have come to the conclusion this study wants to verify, that the__Salafi/Wahhabi approach is largely "authoritarian" and "literalist/textualist", mainly based on an examination of the fatwas or Salafi scholars' views regarding women's issues. My choice to focus on the issues of gazing at the ajnabiyah and gender segregation is primarily due to the fact that these are among a number of issues where strict rules on them are very often ascribed to Salafis - though some of the traditionalists, another group which is also considered a proponent of textualism, might also advocate similarly rigid stances. While so-called traditionalists are considered to deal with the issues in a less rigid manner, Salafis - who are initially more distinctive in terms of their 'aqidah rather than in terms of their fiqh - are repeatedly said to insist on strict rulings on (seeing) women's 'awrah (part of their body which should be covered which, according to Salafis, happens to be their whole body except for the eyes or even one of the eyes) and strict male-female segregation. ${ }^{13}$

Their standpoints on both issues are often justified by a certain

\footnotetext{
${ }^{10}$ There is another contemporary Salafi tafsir written by a popular figure, 'A' id al-Qarni entitled, al-Tafsir al-Muyassar (Riyad: al-'Ubaykan, 2007) but this tafsir is too concise to be included in my analysis.

${ }^{11}$ See Ibn Kathìr, Tafsir al-Qur'ān al- 'Azìm (Mu'assasah Qurțūbah, n.d.), 6-19. 110.

${ }^{12}$ See Ibn Taymìyah, Muqaddimah fị Ușūl al-Tafsìr (Beirut: Dār Ibn Ḥazm, 1997),

${ }^{13}$ This assumption seemingly needs further clarification since strict gender segregation and rigid rules on female 'awrah might extend Salafi and non-Salafi boundaries. See its indication for instance in Muhammad 'Ali al-Șābūní, Tafsìr Ayàt alAhkām min al-Qur'ān (Beirut: Dār al-Kutub al-'Ilmìyah, 1999), vol. 2, 109-112, 254. However, here it suffices to say that Salafis are among renowned advocates of strict legal rulings on these matters.
} 
understanding of the "ayât al-hijāb wa al-nazar" (verses on partition and gazing), i.e. al-Nūr [24]: 30-31 and al-Aḥāa [33]: 53 (sometimes also 59). Therefore, here I will focus (though not exclusively) on how these verses are interpreted in the three tafsirs under scrutiny. In analyzing their interpretation, I will mainly employ two criteria derived respectively from Saeed's definition of textualism and Abou El Fadl's definition of authoritarianism, ${ }^{14}$ namely: 1) the extent to which an interpretation ignores or rejects both the socio-historical context of revelation and that of interpretation, and 2) the extent to which an interpretation "closes the open text", meaning that it denies any possibility to understand the text differently and implies that the text means only "Y" though it has been understood by others to mean " $X$ " or " $Z$ ". This in some way means that here I will chiefly focus on the Salafi exegetes' treatment of the "textuality" of the Qur' an and their treatment of differences in interpretation.

By doing so, I am at risk of merely imposing an outsiders' perspective on Salafi tafsirs. Therefore, in an effort to be more balanced, I will seek to address the problem of ignorance/attentiveness of the context of the Qur'an and the problem of authoritarian/authoritative interpretation through what I consider as their relevant principles of interpretation so as to understand a certain way of thinking which might lie behind their textual/contextual and authoritarian/authoritative approach to the Qur'an. Accordingly, before discussing their interpretation on "hijäb verses", a methodological review of the three tafsirs will be outlined below to shed light on the nature of Salafi hermeneutics, particularly in connection with Salafis" views on the "context" of the Qur' an and the "plurality of interpretation".

\section{Taysīr al-Karìm al-Raḥmān, Aḍ̂ā' al-Bayān, Aysar al-Tafäsīr and Salafi Approaches to the Qur'an}

It might have been often assumed that Salafis generally give preferentiality to the style of what so-called tafsir bi al-ma'thür/tafsir bi alriwāyah ("tradition-based Qur'an exegesis") — mainly because it is presumably far from innovations (bida'), rather than that of tafsir bi al-ra'y/tafsir bi aldirāyah ("reason based Qur'an exegesis"). However, this assumption seems to be not totally correct. Among the three Salafi tafsirs, only Adwā', al-Bayān, a six-volume tafsir, ${ }^{15}$ can be undoubtedly classified a tafsìr bi al-ma'thür, especially one that generally follows the steps recommended by Ibn Taymiyah

\footnotetext{
${ }^{14}$ See the definitions in footnote 1 and 2 .

${ }^{15}$ It is the edition printed by Dār Ihyè', al-Turāth al-'Arabī, Beirut. Aḍ̂ā' was previously printed in nine volumes by Dār 'Ālam al-Fawā'id, Mecca.
} 
and Ibn Kathïr. ${ }^{16}$ Quite the opposite, Taysīr al-Karim al-Rahmān, a one thousand and more-page tafsir, ${ }^{17}$ and Aysar al-Tafásir, a six-volume tafsir, are more similar to tafsir bi al-ra'y in style, the former being comparable to Tafsir al-Jalālayn by Jalāl al-Dīn al-Maḥallì and Jalāl al-Dīn al-Suyūtīi as well as two much shorter contemporary tafsirs, al-Tafsir al-Wajīz by Wahbah al-Zuhayli and al-Tafsir al-Muyassar by another Salafi author 'A'iḍ al-Qarni, while the latter being to some extent comparable to Tafsìr al-Marāghī by Aḥmad Muștafā al-Marāghì but shorter. Of course, Salafis are among Muslims who strongly insist on the need to avoid ra'y (baseless personal opinion) in interpreting the Qur'an, and even consider tafsir with pure ra'y illegitimate, but if one defines tafsir bi al-ra'y as the one that does not display riwāyāt (narrations) in the interpretation, then both Taysir and Aysar can be categorized so. Nonetheless, it is inaccurate to say that al-Sa'di and al-Jazä'irī very much employ rational thinking in interpreting the Qur'an.

While al-Sa'di's Taysīr is best described as a tafsïr ijmāli ("concise

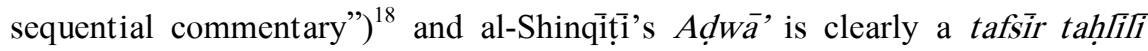
("analytical sequential tafsir"), al-Jazā'iri's Aysar is somewhere in between. Therefore, Taysir and Aysar to a lesser extent, seem to reflect more a premise Salafis hold that the messages of the Qur'an are clear enough, and that understanding the Qur'an is not really a complicated problem-which for one thing implies that there is no need for long-winded interpretation (itna $\bar{a} b$ or tatwil). Both tafsirs represent a broader modern trend of providing a "madeeasy" and "made-simple" (sahl muyassar) tafsir. ${ }^{19}$ This "selling-point" is implied in the titles of both and clearly stated in the introductions to each. ${ }^{20}$ Given the way Salafis see the clarity of Qur'anic messages, some scholars like Wiktorowicz have even suggested that for Salafis, "there is really no such thing

\footnotetext{
${ }^{16}$ That is to find explanation (tafsir) firstly from the Qur'an, then from hadith, and then from the opinions of the companions of the Prophet and then from the opinions of the successors ( $\left.t a \bar{a} b i^{6} u n\right)$. See Ibn Taymìyah, Muqaddimah fí Ușūl al-Tafsìir, 84-109, his al-Tafsir al-Kabïr (Beirut: Dār al-Kutub al-'Ilmiyah, n.d.), vol. 2, 231-244, and Ibn Kathìr, Tafsìr al-Qur'ān al-'Azìim, 6-19. volumes.

${ }^{17}$ It is reported (in the introduction to the book) that it was once printed in five

${ }^{18}$ See for instance Fahd ibn 'Abd al-Rahmān al-Rūmì, Buhüth fí Usùul al-Tafsìr wa Manāhijihi (Maktabat al-Tawbah, n.d.), 59-60.

${ }^{19}$ Other tafsirs within this trend include al-Qarnì's al-Tafsir al-Muyassar, alZuhayli's al-Tafsìr al-Wajīz and 'Ali al-Ṣäbünì's Safwat al-Tafásìr.

${ }^{20}$ See introductions to Taysīr by 'Abd Allāh ibn 'Abd al-'Azīz ibn 'Aqīl and Muhammad al-Ṣālih al-'Uthaymin in Taysìi, 5-7; and al-Jazā'irì's introduction to his Aysar al-Tafásìr li Kalām al-'Alìy al-Kabìr (Medina: Maktabat al-'Ulūm wa al-Ḥikam, 2003), vol. 1, 4-6.
} 
as interpretation". ${ }^{21}$

On the other hand, $A d w^{-\bar{a}}$ is more similar to many of the voluminous classical tafsirs in which extended discussions on certain topics - as well as quotations of sha'a'a'ir or shawāhid 'arābìyah (Arabic poems) - might sometimes interrupt the author's interpretation. Nevertheless, among the three, Aḍa perhaps the best example of a Salafi tafsir built on the premise that the Qur'an is self-explanatory - a premise that Salafis also strongly hold. While it largely follows the tradition of interpretive methodology endorsed by Ibn Taymiyah, $A d w^{\bar{a}}$ ' is quite different from the tafsirs of Ibn Kathir or Ibn Qayyim (two prominent disciples of Ibn Taymiyah) in that it is mostly based on an intensive application of the methodology of interpreting the Qur'an by the Qur'an itself, rather than heavily relying on hadith like Ibn Kathïr's tafsir. Aḍwā' is even arguably one of the most intensive tafsirs in terms of the application of crossreferential hermeneutics. ${ }^{22}$

The three Salafi authors, however, unanimously follow the spirit of Ibn Taymiyah's “anti-ta'will' when dealing with "ambiguous verses" (âa $\bar{a}$ mutashābihāt). ${ }^{23}$ Al-Jazā'iri states in his introduction to his tafsir that it follows manhaj al-salaf when interpreting verses related to 'aqīdah and asmā' wa alsifat. $^{24}$ Muhammad al-'Uthaymin says the same with regard to al-Sa'di's tafsir. ${ }^{25}$ Al-Shinqiti himself wrote a book arguing against the existence of majā ("allegorical/metaphorical" expressions) in the Qur'an, Man' Jawāz al-Majāz fí al-Munazzal li al-Ta'abbud wa al-I'jä, which is attached in the last volume of $A d w_{a \bar{a}}{ }^{26}$ This "anti-ta'wìl' attitude is reflected for instance in their interpretation (or rather: lack of interpretation) of al-hurüf al-muqatta'ah

\footnotetext{
${ }^{21}$ Wiktorowicz, "Anatomy", 210. For a comparable statement see Dudireja, Constructing a Religiously Ideal, 191.

${ }^{22}$ My preliminary research comparing his tafsirs with other tafsirs known for their serious attention to tafsir al-Qur'ān bi al-Qur'ān reveal that $A d_{\text {W }} \bar{a}^{-}$' is the most focused in citing relevant verses in other parts of the Qur'an while interpreting a certain word, verse or group of verses. Taking the case of suras al-Fātihah and Qāf as samples, $A d_{\text {ôa }} \bar{a}^{-}$ cites on average 8.9 times on each page, while al-Rāzi's Mafatịh al-Ghayb cites 3.4 times/page, al-Qāsimī's Maḥāsin al-Ta'wīl cites 1.8 times/page, Ibn Kathïr's Tafsìr alQur'ān al- 'Ażìm cites 1.7 times/page, and al-Ṭabāṭabā'i's al-Mizzān cites 1.3 times/page.

${ }^{23}$ For the discussions on how al-Sa'di and al-Shinqiți interpret àyāt al-șifăt, read Muhammad ibn 'Abd al-Raḥmān al-Mighrāwì, al-Mufassirūn bayna al-Ta'wīl wa alIthbàt fí Ayàt al-Sifät (Beirut: Mu' assasat al-Risālah, 2000), 694-705.

${ }^{24}$ Al-Jazā'irì, Aysar al-Tafāsìr, vol. 1, 6.

${ }^{25} \mathrm{Al}-\mathrm{Sa}$ 'di, Taysīr al-Karim al-Rahmān, 7.

${ }^{26}$ See al-Shinqițī, Adwā' al-Bayān, vol 6, 389-410. The belief whether or not majaz exists in the Qur'an surely affect the way exegetes interpret șifat-related verses.
} 
(initial letters in the beginning of suras). ${ }^{27}$

While for Salafis following the manhaj is of utmost importance to avoiding any misunderstanding of what God means, for critics it would mean a blunt opposition to rationalism. They have argued that Salafis adhere to the text to a point where they consider the application of human intellect and logic (rationalism) to the Qur'an to be dangerous. "Any time humans attempt to apply their own logic or methods of reasoning ... they open the way to human desire, distortion, and deviancy. Approaches that are guided by human logic will necessarily fall foul of human desire, which will lead to the selective and biased extrapolation of religious evidence to support human interests rather than religious truth." 28

In addition to their similarities in their treatment of 'aqidah verses, to a certain degree the three tafsirs are equally concerned with ahkām verses. AlShinqiti himself states that one of his objectives in $A d w^{-}{ }^{-}$' is to provide explanations of àyät al-ahkām in the Qur'an. A close look at Taysīr and Aysar will reveal a similar conclusion. With regard to Aysar, it is understandable that one of al-Jazä'iri's aims is for the readers to focus more on how to implement the Qur'an. ${ }^{29}$

Nevertheless, when addressing differences of opinion/interpretation, the three tafsirs have different attitudes. While Aysar and Taysir consciously avoid mentioning ikhtilāf among exegetes, $A d_{W} \bar{a}^{\bar{a}}$, frequently mentions different opinions, particularly with regard to àyât al-ahkām - though the author seems to always mention what he regards as the strongest of opinions. For the authors of Aysar and Taysir, the intentional avoidance of mentioning differences in

${ }^{27} \mathrm{Al}-\mathrm{Sa}$ ' di simply mentions that the safest is "al-suküt" (silencing) what it might mean and be sure that there exists a hikmah (wisdom) we do not know, or simply mentions that no one knows its meaning except for Allah, or simply makes no comments on those letters. Similarly, al-Jazā'iri simply suggests that such letters are a part of mutashäbih of which only God who knows its meaning, or simply mentions that the salaf's school regarding such letters is to say, "God knows its intended meaning." In the

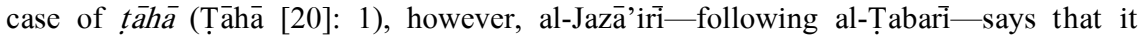
means "O man", an opinion that is disapproved by al-Shinqiți. Al-Shinqiți himself rarely gives any comment on those letters, but explains his preference while interpreting Hūd [11]: 1. Implementing the method of istiqra', al-Qur'an, he follows the conclusion of alRàzí, Ibn Kathìr and Ibn Qayyim al-Jawziyah that such letters are an indication that the subsequent discussion in a sura, where those letters are mentioned, deals with the

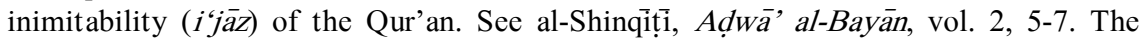
function of these letters as a sign of $i^{\prime} j \mathrm{j} a \mathrm{z}$ has been discussed in more detail by 'A'isha Bint al-Shāti' in her al-I'jāz al-Bayānì li al-Qur'ān and al-Tafsìr al-Bayānì li al-Qur'ān al-Karim.

${ }^{28}$ Wiktorowicz, “Anatomy”, 210.

${ }^{29}$ Al-Jaza'iri, Aysar al-Tafäsir, vol. 1, 6. 
interpretation (ighfäl al-khiläfät al-tafsiriyah in al-Jazä'irī's term or tajannub dhikr al-khiläf in al-'Uthaymin's word while introducing al-Sa'di's tafsir) is another "selling-point" of both tafsirs, and seems to have something to do with the perceived need for "uniting Muslims in a unified, correct and good Islamic thinking" (jam' al-muslimīn 'alā fikr islämī muwahhịid șà'ib salim). ${ }^{30}$ For Salafis, what is considered "correct" when looking at differences of interpretation is usually the one that is exemplified by exegetes among the Companions or the Successors-whom they call jumhür al-mufassirin min alsalaf al-șälih. In the case of al-Jazā'iri, the "selected" opinion from existing different interpretations is usually, as he himself states, relied upon al-Ṭabari's preference. $^{31}$

It might often be argued that in terms of the truth one can achieve through interpretation, Salafis view that there is an objective meaning that we can take hold of, and there is only one legitimate religious interpretation. It has also been argued that for Salafis Islamic pluralism does not exist, and if it seems exist, it should be avoided. $^{32}$ In critics' words, Salafis approach the authoritative text to a point that they identify with and represent the text or the singular truth revealed by the text; they consider their understanding as the only "correct" one and reject any possible meaning other than their understanding. However, if one looks at al-Shinqițî's tafsir in particular, this perceived single legitimate, objective interpretation is achieved in a more argumentative manner. Al-Shinqiți heavily relies on what the Qur'an tells in other verses to determine what is intended by a certain word or phrase in a particular verse. His manner of interpretation is perhaps more "textualist" but less "authoritarian". Meanwhile in the case of al-Jazā'iri's tafsir, this "single legitimate" is achieved through reliance on a selected "authoritative" salaf. In the name of practicality and the unity of umma, he transforms what the critics would consider as an "unauthoritarian" way of interpretation into what they would consider as an "authoritarian" way of interpretation, a negligence of multiple understandings and the complexity of meaning. If his interpretation is to be considered "authoritarian", one can now learn how such an "authoritarian" reading is constructed through not only a historical leap, but also a selective mannerlimiting to one among different salaf s interpretations-which they regard mainly contain ikhtiläf tanawwu' (corresponding difference), and not ikthiläf

\footnotetext{
${ }^{30}$ Al-Jaza'iri, Aysar al-Tafâsìr, vol. 1, 6. Al-Sa‘di, Taysìr al-Karìm al-Raḥmān, 7.

${ }^{31}$ Al-Jaza'iri, Aysar al-Tafāsīi, vol. 1, 6.

${ }^{32}$ See for instance Wiktorowicz, “Anatomy”, 207.
} 
taḍậ (contradictory difference). ${ }^{33}$

Hermeneutics in the three tafsirs is largely "text-centered", rather than "reader-centered", and "language-oriented" rather than "discourse-oriented". 34 In their text-centered hermeneutics, remains a very limited attention to the socio-historical context of the Qur'an — as is the case with many tafsirs. Apart from mentioning asbāb al-nuzūl, there is hardly any reference both to the past and present contexts. This "textualist" tendency can to some extent be attributed to the principles tafsirs Salafis consider to be important in order not to misunderstand what the Qur'an means. Al-Sa'di's method of interpretation itself is noticeably based on the principles - many of which deal with deriving “general" Qur'anic rulings with linguistic analysis - outlined by Ibn Qayyim which readers can read in the beginning, and is partly summarized at the end of al-Sa'di's book. ${ }^{35}$ A notable emphasis on the "generality/universality" of the text is also apparent in al-Shinqītī's tafsir-and that of al-Jazā'iri as well except that the latter is often satisfied with simply following the conclusion of alTabari while al-Shinqitîi focuses more on the application of his own interpretive methodology.

\section{The Rulings on Gazing at Women and Male-Female Segregation in Salafi Tafsirs}

The three tafsirs under discussions by and large come to the same conclusion regarding these two issues: 1) that gazing at any part of the ajnabiyah's body is forbidden, and 2) that there should be no free mixing (ikhtilat) between male and female. Their argument principally is this: free mixing is prohibited since gazing at a woman (as well as talking to a woman face to face) is prohibited, and gazing at a woman is prohibited since all parts of her body (except for her eyes) are considered 'awrah (private part/shame of sex) which should remain veiled; and gazing at 'awrah is prohibited since gazing might results in "dirt heart/a dirty heart", "lust" (shahwah) and even "adultery" $\left(\right.$ zina). ${ }^{36}$

\footnotetext{
${ }^{33}$ How Salafis see differences among salafs is very much influenced by this distinction made by Ibn Taymīyah between ikhtiläf tanawwu' and ikhtiläf taḍa de. See his Muqaddimah fí Ușūl al-Tafsìr, 36; Iqtị̣ā' al-Sirāt al-Mustaqīm Mukhālafat Aṣ̣āa alJahịm (al-Majd al-Tijāriyah, n.d.), 37-39; and al-Tafsir al-Kabir, vol. 2, 196.

${ }^{34}$ For this distinction between "language" and "discourse" derived from the linguist and literary theorist Tzvetan Todorov, see Saeed, Interpreting the Qur'an, 106107.

${ }^{35}$ See al-Sa‘di, Taysìr al-Karìm al-Raḥmān, 14-20, 1043-1046.

${ }^{36}$ Both the conclusion and argument are not actually uncommon among Muslim exegetes. See some comparable conclusions and arguments (but sometimes with minor
} 
Even though our focus here is on the way they interpret the hijäb verses, rather than on the conclusion they make itself, here one would pay attention to their steps to come to the conclusion while interpreting the verses. There are some terms or concepts in al-Nūr [24]: 30-31 and al-Ahzāb [33]: 53 which are understood as implying that for a male adult (mumayyiz), seeing an "unrelated" woman (particularly whose 'awrah is not totally masked) is forbidden, and that there should be a "veil/curtain" between male and female adults: 1) ghaḍ albașar (lowering gaze/casting down eyes), 2) ibdā', al-zinah (displaying/showing off adornments), and 3) (mukhătabah) min warā' hijāb (talking from behind a curtain/screen).

As it might be predicted, given their conciseness and tendency to consciously display only one interpretation, even when dealing with differences, Taysïr and Aysar are more straightforward in highlighting these "clear" instructions in the verses. The author of Taysir understands the first instruction (ghadd al-basar) as casting down one's eyes from looking at the 'awrah and "unrelated" men or women with lust or from similar forbidden looks. ${ }^{37}$ He then proceeds with what is meant by al-zinah which for him includes clothes, jewels and all parts of a woman's body, and by the exception in the verse (understood from the phrase illa mā zahara minhā) which means "their visible clothes". The understanding of al-zinah as including all parts of a woman's body, to al-Sa'di, is indicated by the sequential instruction of idrāb al-khumūr 'ala al-juyūb (drawing the veils/headcovers over the bosom). And with regard to talking to a woman min wara $\bar{a}$ ' hijāb, he understands it as implying that looking at a woman is forbidden $\left(m a m n \bar{u}^{\circ}\right)$ in any situation (bi kull hă $)$. He then explains that the hikmah of this instruction mentioned in the phrase dhālikum athar li qulübikum wa qulübihinna (that is purer for your hearts and their hearts) indicates a principle of sharia that jamī' wasā'il al-sharr wa asbābuhu wa muqadimmātuhu mamn $\bar{u}^{\prime} a h$ (any means, cause and preliminary of wrongdoing is prohibited).

In interpreting these verses, as is the case with the majority of Qur'anic verses, the author of Taysïr neither displays any linguistic analysis, mentions any hadith (riwāyah) to support his conclusion, quotes any other relevant verses, mentions a principle of ușül al-fiqh or ușūl al-tafsìr, discusses different socio-cultural contexts, nor mentions any different opinions. This is also the case with the author of Aysar-except that he mentions the occasions of

difference in terms of the limits of 'awrah) in Muhammad ibn Ahmad al-Anșāāi alQurțūbì, al-Jāmi ' li Ahkām al-Qur'ān (Cairo: Dār al-Ḥadith, 2002), vol. 6, 513-519; 'Ali al-S̄ābūni, Tafsìr Ayàt al-Ahkām, vol. 2, 109-115, 254.

${ }^{37} \mathrm{Al}-\mathrm{Sa}$ ‘di, Taysīr al-Karìm al-Rahmān, 615. 
revelation (asbāb nuzūı) in interpreting 33: $53 .{ }^{38}$

Compared to al-Sa'di, al-Jazā'irī however at one point has a different understanding of ibda', al-zinah which means to him revealing parts of a women's body which serve as places of jewelry (mawädi ${ }^{\text {‘ }}$ al-zinah), and of the exception, illā mā zahara minhă, as the one that could not surely be hidden like eyes, palms or clothes. While interpreting the jilbāb verse, 33: 59, he goes further to briefly mention that today there is even no need for not covering eyes, since a woman can use a thin layer (qumassh raqiq) to veil her eyes and at the same time can still look at the street she is passing along. ${ }^{39}$ In addition, he firmly stresses that 33: 53 in part explains that a man would have a certain degree of "wicked imagination" (khawätir al-sū') when talking to and looking at a woman. ${ }^{40}$

On the other hand, the author of $A d w^{-a}$ ' does many of the things that the authors of Taysir and Aysar do not do. He slightly discusses a linguistic problem by quoting classical exegetes like al-Zamakhshari and al-Qurțūbi, as well as quoting some relevant shi'rs. He discusses some seemingly contradictory hadiths relevant to understanding of the verses. He mentions many relevant verses useful to better understand the verse under discussion. He mentions some principles of uṣūl al-tafsìir. Above all, he mentions different interpretations and subsequently argues against some of the interpretations, but finally declares that wa Allāh ta'ālā a 'lam (God the Exalted knows best).

While interpreting sura 24: $31,{ }^{41}$ al-Shinqiți sums up the different interpretations of zinah into three viewpoints: 1) that it means parts of a woman's body, 2) that it means ornaments/jewels a woman uses for her beauty which do not necessarily require a part of her body to be revealed, 3) that it means ornaments a woman uses for her beauty which necessarily require a part of her body to be revealed. ${ }^{42}$

Al-Shinqị̂i then proceeds with quotations from Ibn Kathïr, al-Qurțūbi, al-Zamakhshari and al-Suyūtị (who mention interpretations of earlier generations) before once again asserting that the differences among salaf can be summarized in those three categories, and that for him the second (that zinah

${ }^{38}$ Al-Jaza'iri, Aysar al-Tafāsìi, vol. 4, 287, 291.

${ }^{39}$ Al-Jaza'iri, Aysar al-Tafäsìi, vol. 4, 292.

${ }^{40}$ Al-Jaza'iri, Aysar al-Tafásì, vol. 4, 289.

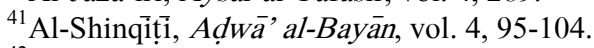

${ }^{42}$ Al-Jaza' 'riri's position would fit the last, while al-Sa'di's stance is more a combination between the first and the second. Al-Jaza' 'iri's position in this case is a bit different from al-Tabari (the exegete he often relies on) who prefer the opinion that the exception of zinah refers to the palms and the face. See Ibn Jarir al-Tabari, Jämi ${ }^{\circ}$ alBayān fì Ta'wìl al-Qur'ān (Beirut: Dār al-Kutub al-'Ilmìyah, 2005), vol. 9, 306. 
means something outside her body [khilqah] which does not necessarily require a part of a woman's body be seen) which implies that mā zahara minhā means her clothes, is the clearest and most careful stand. ${ }^{43}$

Al-Shinqiți then mentions some principles of tafsir (he often uses in his tafsir) which support his argument, namely the identification of qarinah fi nafs al-ayah (evidence in the same verse) and the identification of the most usual intended meaning of the word in the Qur'an (al-murād min al-lafz fí al-ghālib) to see whether an interpretation is appropriate - two principles that he also uses in interpreting the hijāb verse in al-Ahzāb. Implementing both principles, alShinqiți argues that the first opinion is invalid. The choice is thus now only between the second and the third.

Al-Shinqiți then uses the principle of "carefulness" (ihtiyăt) to weigh the second over the third. The second, he argues, is farther from the illah (underlying reason) of the prohibition of gazing at a woman (i.e. fitna and tuhür al-qalb) and thereby more preventive from any disallowed occurrence.

Moreover, again arguing against the first and the third opinions, alShinqiți asserts the poor quality of a hadith indicating that a woman's 'awrah excludes her face and palm.

While interpreting 33: 53, ${ }^{44}$ al-Shinqiti also uses the two abovementioned principles of tafsir to argue against those who consider that the instruction of talking min warā' hijāb only applies to the Prophet's wives. The reasoning (ta'Til) mentioned in the verse (dhālikum athar liqulübihim wa qulübihinna) is universal/general and thereby the hukm (ruling) is also universal/general. He argues that this principle, that the generality of 'illah means the generality of hukm, is already well-known in uṣül al-fiqh.

Al-Shinqiți further supports his argument with other relevant Qur'anic verses (33: 59, 60 and 24: 31). He explains how these verses support his argument and argues against those who interpret these quoted verses differently. He supports the authoritativeness of his interpretation with that of exegetes among the Companions-who relate the verse with its sabab nuzülas well as linguistic argumentation.

${ }^{43}$ It should be noted that al-Shinqitịi's stand on the meaning of zinah is different from that of al-Qurtübì (an exegete from whom he quotes some narrations) and earlier narration-minded exegetes like al-Ṭabari (as mentioned in the previous footnote). His view is also a bit different from, but closer to, that of al-Zamakhshari. See al-Qurtūibi, alJāmi' li Aḥkām al-Qur'ān, vol. 6, 519; Abū al-Qāsim Mạ̣mūd al-Zamakhsharī, al-

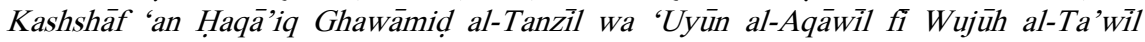
(Riyad: Maktabah al-'Ubaykān, 1998), vol. 4, 289-291.

${ }^{44}$ Al-Shinqīìi, Aḍ̂à' al-Bayān, vol. 4, 287-297. 
Again he asserts another similar principle of ușūl which supports the generality of the hijāb instruction, namely that khitāb al-wāhid ya'ummu ḥukmuhu jamī' al-ummah, wa lā yakhtașsu al-ḥukm bi dhālika al-mukhạtab alwăhid, and stresses the soundness of this principle.

He then argues against those who support the specificity of the hijab instruction only to the Prophet's wives by employing a logic: if it was only for the Prophet's wives, they surely are good examples (uswah) for all Muslim women. ${ }^{45}$

Subsequently al-Shinqiți mentions and discusses some hadiths (and quotes their interpretations by Ibn Hajar) which support the generality of the instruction as well as supporting the interpretation of iḍa $\bar{a} b$ al-khumur 'ala aljuyūb as veiling the face. He then feels the need to briefly assert the position of hadith as the mubayyin of the Qur'an by quoting a relevant verse. Next he expresses his amazement with those who say that there is neither Qur'anic verse nor hadith which show the obligation for women to veil their face in the presence of "unrelated" men (ajānib).

Later al-Shinqiți cites some hadiths, stating that a woman is 'awrah, which support the obligation of hija $\bar{b}$ and discusses some hadiths used by those who argue for the permissibility of women to unveil their face and palms in the presence of the ajanib. He shows the poor quality of these hadiths, or otherwise, clarifying that the hadiths seemingly indicating that women did not veil their face during the Prophet's time do not really point out that they unveil their face intentionally.

Finally, de-legitimizing other interpretations, al-Shinqiți concludes that God (al-Shäri ${ }^{\circ}$ prohibits women from unveiling their face before the ajāib, since the face is așl al-jamāl (the source of beauty) and looking at a young beautiful woman's face is a threshold into seduced human desire (gharizah basharīyah) and might lead to unexpected occurrences. Al-Shinqiți goes further to briefly explain relevant topics - shaking hands with a woman and touching her body, both of which are not allowed.

Even though al-Shinqiți arrives at a dissimilar conclusion, just like alSa'di and al-Jazā'iri, al-Shinqīti certainly shows his readers other ways of understanding the verses and provides them with a door to either support or criticize his interpretation.

${ }^{45}$ According to al-Shinqitîi, the majority of Muslim scholars agree that the Prophet's wives had veiled their face even before the revelation of hijäb verse. Therefore this verse would be meaningless if one understands it as applying only to his wives. 


\section{Concluding Remarks}

As far as the discussions on some of the issues around hijäb verses in the three Salafi tafsirs are concerned, one can arrive at a conclusion that these Salafi tafsirs are basically "textualist". Apart from a very limited discussion on asbāb al-nuzūl hadiths, they generally ignore the context of revelation and that of interpretation, and instead-in the case of al-Sa'di's and al-Jazà'iri's tafsirs - focus on what the verses "textually" or "literally" mean or-like in the case of al-Shinqiți's tafsir-focus on providing Qur'an/hadith/ușül-based arguments to support this "literal" meaning. At best one could pay much attention to some of what Saeed calls as the "broad context" of the Qur'an, which also includes the overall content of the Qur'an, ${ }^{46}$ in al-Shinqițî's $A d w^{-} \bar{a}^{-}$.

Nonetheless, though they essentially ignore the socio-historical contexts of the Qur'an in interpretation, Saeed's complete definition of textualism cannot fully be applied to all of these tafsirs since "Taysir's and Aysar's textualism" neither overtly reflect much reliance on hadith nor approach the question of interpretation strictly from a linguistic perspective. Their textualism might be better described by another of Saeed's distinctions between the two forms of literalism, namely "soft" literalism and "wooden" literalism, ${ }^{47}$ assuming that the latter can aptly describe this kind of textualism.

Above all, this kind of textualism or ignorance of the contexts in Salafi tafsirs might be attributed to their emphasis on the "generality" of the text ( 'umümiyyat al-alfaz) — which is very noticeable in the interpretation of hijäb verses in al-Shinqițí's $A d w_{w a} \bar{a}$. For Salafis, the text is considered to have superiority over the context. As is the case with many textualists, they focus more on "direct meaning" than "indirect meaning", 48 and treat the Qur'an more as "language" than as "discourse" (language in context).

While Adwa' might not be fittingly characterized "authoritarian" (at least "less authoritarian") as it shows the readers different interpretations of the text despite arriving at a dissimilar conclusion regarding the prohibition of gazing at an "unrelated" woman's body and the obligation of hijäb, Taysir and Aysar seem to be more exposed to Abou El Fadl's "authoritarian/authoritative"

\footnotetext{
${ }^{46}$ See Saeed, Interpreting the Qur'an, 105. His distinction between "broad context" and "narrow context" is fairly comparable to Bint al-Shati's distinction between al-siyāq al- 'āmm (general context) and al-siyāq al-khāsș (specific context).

${ }^{47}$ Saeed, Interpreting the Qur'an, 113. "Soft" literalism emphasizes the literal meaning and makes it the basis for the exploration of the whole meaning of the text, while "wooden" literalism is "a rigid understanding of the literal meaning of the words without any regard to the complexities associated with meaning."

${ }^{48}$ For this distinction, see Saeed, Interpreting the Qur'an, 105.
} 
criticism. Both tafsirs do not allow the reader to know other possible understandings of the interpreted text. There is a high degree of what Saeed terms "rigidity" 49 in these two tafsirs as both attempt to limit the meaning of ethico-legal text to one. Though, this might also be said of $A d W^{\bar{a}}$ - as is also the case with many modern textualists - which still contains rigidity since it to borrow Saeed's words - "argues against the legitimacy of other possible meanings of the same text." 50

The "authoritarian" nature in at least some of Salafi tafsirs to some extent might be attributed to their stated aim to "unite" the umma under a single, correct (and "simple") interpretation. However, from the critics's viewpoint, this surely means an act of "locking" the Divine Will. Wa Allăh a'lam.[]

\section{Bibliography}

Abou El Fadl, Khaled. And God Knows the Soldier: The Authoritative and Authoritarian in Islamic Discourse. Maryland: University Press of America, 2001.

-------. Speaking in God's Name: Islamic Law, Authority and Women. Oxford: Oneworld, 2001.

The Great Theft: Wrestling Islam from the Extremists. San Francisco: HarperCollins, 2007.

Campanini, Massimo. The Qur'an: The Basics. Translated by Oliver Leaman. London \& New York: Routledge, 2007.

Dudireja, Adis. Constructing a Religiously Ideal "Believer" and "Woman" in Islam: Neo-traditional Salafi and Progressive Muslims' Methods of Interpretation. New York: Palgrave Macmillan, 2011.

Ibn Kathïr. Tafsìr al-Qur'ān al- 'Azīim. Mu'assasah Qurțūbah, n.d.

Ibn Taymīyah. al-Tafsïr al-Kabïr. Beirut: Dār al-Kutub al-'Ilmìyah, n.d.

Ibn Taymìyah. Iqtị̣ā' al-Ṣirạt al-Mustaqīm Mukhālafat Aṣhāb al-Jaḥim. alMajd al-Tijāriyah, n.d.

Ibn Taymìyah. Muqaddimah fĩ Uṣūl al-Tafsìr. Beirut: Dār Ibn Ḥazm, 1997.

\footnotetext{
${ }^{49}$ Saeed, Interpreting the Qur'an, 104.

${ }^{50}$ It might be important to stress that their rigidity is much higher from some exegetes whose tafsirs many Salafis would consider as parts of Salafi tradition, such as al-T abari and Ibn Kathir. This difference is also apparent in the interpretation of al-Nür [24]: 30-31. See al-T abarì, Jämi' al-Bayān, vol. 9, 303-307; Ibn Kathïr, Tafsìr al-Qur'ān al-'Azim, vol. 10, 212-225.
} 
al-Jazā'irīi, Abū Bakr Jābir. Aysar al-Tafāsìr li Kalām al- 'Alìy al-Kabỉr. Medina: Maktabat al-'Ulūm wa al-Hikam, 2003.

al-Qarnī, 'A'iḍ. al-Tafsiri al-Muyassar. Riyad: al-'Ubaykan, 2007.

al-Qurțūbī, Muḥammad ibn Aḥmad al-Anșāīi. al-Jāmi‘ li Aḥkām al-Qur'ān. Cairo: Dar al-Hadith, 2002.

al-Mighrāwī, Muḥammad ibn 'Abd al-Raḥmān. al-Mufassirūn bayna al-Ta'wīl wa al-Ithbāt fí Ayāt al-Sifät. Beirut: Mu' assasat al-Risālah, 2000.

al-Rūmī, Fahd ibn 'Abd al-Raḥmān. Buḥūth fî̀ Ușūl al-Tafsīir wa Manāhijihi. Maktabah al-Tawbah, n.d.

al-Sa'dī, 'Abd al-Raḥmān ibn Nāṣir. Taysīr al-Karīm al-Raḥmān fỉ Tafsìir Kalām al-Mannān. Cairo: Dār al-Ḥadith, 2005.

al-Ṣābūnī, Muhammad 'Alì. Tafsìir Ayāt al-Ahkāmm min al-Qur'ān. Beirut: Dār al-Kutub al-'Ilmìyah, 1999.

Saeed, Abdullah. Interpreting the Qur'an: Towards a Contemporary Approach. London \& New York: Routledge, 2006.

al-Shinqīịi, Muhammad al-Amīn. Adwā' al-Bayān fî I ḍạh al-Qur'ān bi alQur'ān. Beirut: Dār Ihyầ' al-Turāth al-'Arabī, n.d.

al-Ṭabarī, Ibn Jarīr. Jāmi ' al-Bayān fì Ta’wìl al-Qur'ān. Beirut: Dār al-Kutub al'Ilmiyah, 2005.

Wiktorowicz, Quintan. “Anatomy of the Salafi Movement." Studies in Conflict \& Terrorism 29 (2006): 207-239.

al-Zamakhsharī, Abū al-Qāsim Mạ̣mūd. al-Kashshāf 'an Haqā'iq Ghawāmị̣ al-Tanzīl wa 'Uyūn al-Aqāwīl fì Wujūh al-Ta'wīl. Riyad: Maktabah al'Ubaykān, 1998. 